\title{
Antibacterial activity and physicochemical characteristics of honey from Mato Grosso's Amazon, Cerrado and Pantanal, Brazil
}

The objective of this is report was to evaluate the physicochemical characteristics and the antibacterial activity of honey produced for human consumption in some counties in Amazon, Cerrado and Pantanal of Mato Grosso, Brazil. Honey samples were collected in 6 municipalities, totaling 18 samples, 3 samples per municipality. The physicochemical characteristics evaluated were moisture, reducing sugars, apparent sucrose, glucose and fructose by HPLC system, ashes, insoluble solids, free acidity, HMF, diastase activity, Lund, Fiehe and Lugol reactions, electrical conductivity and color. The content of total phenolic and flavonoids were quantified using standard curve of gallic acid and quercetin. The antibacterial activity of honey was evaluated by disk diffusion to five bacteria. Fifteen out of eighteen samples were reproved in some of the physicochemical characteristics. Honeys' average content of total phenolic was $35.68 \mathrm{mg}$ GAE/100 g of honey. The content of total phenolic and flavonoids showed positive correlation with the color of the honeys. The studied honeys did not present antibacterial activity, but the phenolic and flavonoid contents originate potential antioxidant and prebiotic for the darkest honeys. Mato Grosso has potential to the production of the floral honey, in need of adequacy on the quality of the honey to the physicochemical characteristic's patterns.

\section{Atividade antibacteriana e características físico-químicas do mel da Amazônia, Cerrado e Pantanal de Mato Grosso, Brasil}

\begin{abstract}
O objetivo deste trabalho é avaliar as características físico-químicas e a atividade antibacteriana do mel produzido para consumo humano em alguns municípios da Amazônia, Cerrado e Pantanal do Mato Grosso, Brasil. Amostras de mel foram coletadas em 6 municípios, totalizando 18 amostras, 3 amostras por município. As características físico-químicas avaliadas foram: umidade, açúcares redutores, sacarose aparente, glicose e frutose pelo sistema HPLC, cinzas, sólidos insolúveis, acidez livre, HMF, atividade diastásica, reações de Lund, Fiehe e Lugol, condutividade elétrica e cor. O teor de fenólicos totais e flavonóides foi quantificado usando curva padrão de ácido gálico e quercetina. A atividade antibacteriana do mel foi avaliada por disco difusão a cinco bactérias. Quinze das dezoito amostras foram reprovadas em algumas das características físico-químicas. O teor médio de fenólico total dos méis foi de 35,68 mg GAE / $100 \mathrm{~g}$ de mel. 0 teor de fenólicos totais e flavonóides apresentou correlação positiva com a cor dos méis. Os méis estudados não apresentaram atividade antibacteriana, mas os teores de fenólicos e flavonóides originaram potencial antioxidante e prebiótico para os méis mais escuros. Mato Grosso tem potencial para a produção do mel floral, necessitando de adequação na qualidade do mel aos padrões das características físico-químicas.
\end{abstract}

Keywords: Flavonóides; Fenólico; Cor.

Topic: Uso Sustentável da Biodiversidade

Reviewed anonymously in the process of blind peer.
Received: 02/02/2018

Approved: 20/05/2018
Gabriela Maria Franz

Universidade do Estado de Mato Grosso, Brasil http://lattes.cnpq.br/8309193920543284 gabrielamfranz@gmail.com

\section{Carla Galbiati}

Universidade do Estado de Mato Grosso, Brasil http://lattes.cnpq.br/4449909695203792 carla@unemat.br

\section{Elias da Silva Araujo}

Universidade de São Paulo, Brasil http://lattes.cnpq.br/9710177100351578 esacamelo@usp.br
Ligia Bicudo de Almeida-Muradian Universidade de São Paulo, Brasil http://lattes.cnpq.br/0120855945581915 ligiabi@usp.br
Referencing this:

FRANZ, G. M.; GALBIATI, C.; ARAUJO, E. S.; ALMEIDA-MURADIAN, L. B.. Antibacterial activity and physicochemical characteristics of honey from Mato Grosso's Amazon, Cerrado and Pantanal, Brazil. Revista Ibero-Americana de Ciências Ambientais, v.9, n.1, p.26-42, 2018. DOI: http://doi.org/10.6008/SPC2179-6858.2018.001.0003 


\section{INTRODUCTION}

The production and quality of honey are positively influenced by the richness of species, number of flowers and close to native forests (SANDE et al., 2009; ALVES et al., 2011), which makes Mato Grosso, a potential state to beekeeping production in Brazil.

The state consists of three biomes of high biodiversity: Amazon (53.6\% of the territory), Cerrado (39.6\%) and Pantanal (6.79\%) (MATO GROSSO, 2013). Nevertheless, Mato Grosso occupies the $16^{\text {th }}$ place in the country's honey production, with a total of 379 tons/year (IBGE, 2013). These is because of the lack of political and economic projects, structure associations and enable beekeepers (DALLEMOLE et al., 2010).

The floral honey bee Apis mellifera $\mathrm{L}$. is a food product produced from the nectar of flowers (AZEREDO et al., 2003), consisting of supersaturated solution of sugars, primarily fructose and glucose and other minority compounds such as proteins, enzymes, amino acids, organic acids, lipids, vitamins, phenolic acids, flavonoids, carotenoids and minerals giving the honey nutritional property and functional activity (ALVAREZSUAREZ et al., 2010; KHALIL et al., 2011).

Interest in natural products with functional activity has grown in recent years, which has generated a growing demand for bee products (BALTRUŠAITYTĖ et al., 2007), due to their nutritional and therapeutic properties (SANT'ANA et al., 2012).

The honey ability to inhibit the growth of several Gram positive and Gram negative comes possibly from their flavonoids and phenolic compounds (ALVAREZ-SUAREZ et al., 2010; ESCUREDO et al., 2012), which are produced by secondary metabolism plants and are responsible also for the antioxidant effect (SILICl et al., 2010). The darker honeys have higher concentrations of secondary compounds such as phenolics, flavonoids and carotenoids and consequent greater antimicrobial activity (ALVAREZ-SUAREZ et al., 2010).

The Manuka Honey from New Zealand, monofloral Leptospermum scoparium, own evidenced antimicrobial activity. Bacteria are not able to manifest resistance to natural product and even strains multiresistant to antibiotics and drugs may be susceptible to this honey (BLAIR et al., 2009; COOPER et al., 2010). To combat multidrug-resistant bacteria used the synergism between antibiotics and honey and have found that an amount of honey added to the antibiotic enhances its effect (JENKINS et al., 2012).

The physicochemical, sensorial and microbiological characteristics determine the honey quality. The physicochemical analysis can verify the authenticity of the product and detect tampering or the presence of artificial components, guaranteeing food safety for consumers (ABADIO FINCO et al., 2010; BELAY et al., 2013).

The authenticity of honey is defined by legislation of country of origin (CAC, 2001), which, in Brazil follow the Normative Instruction $\mathrm{n}-11$, of October $20^{\text {th }} .2000$, elaborated by the Ministry of Agriculture, Livestock and Supply (BRASIL, 2000). Nevertheless, the labeling of honey has not always met the requirements of Brazilian law (BERA et al., 2005).

The Brazilian honey has been considered in good physicochemical quality, with some exceptions. The Brazilian honey from Bahia was in accordance with the legislation (LACERDA et al., 2010), but 50\% of honey 
samples from Tocantins were disapproved in relation to legislation (ABADIO FINCO et al., 2010). Excellent quality was found in $87 \%$ of samples of organic honey from the Paraná River islands (ALVES et al., 2011). The honey in Ceará was considered with good quality to the physicochemical characteristics, except to HMF content (ALMEIDA-MURADIAN et al., 2013).

The increase in honey production can be achieved with the appreciation of the use and consumption of the product, through the proof of their therapeutic and biological activity. Furthermore, there is a need to develop new classes of antibiotic based on natural products which microorganisms do not exhibit resistance.

The objective of this report was to evaluate the physicochemical characteristics and the antibacterial activity of honey produced for human consumption in some counties in Amazon, Cerrado and Pantanal of Mato Grosso, Brazil.

\section{MATERIAL AND METHODS}

\section{Study area and collecting honey}

Honey samples from A. mellifera bee were collected in six municipalities of Mato Grosso, Brazil (Figure 1). A total of 18 samples were collected during the study, 3 samples per municipality.

The municipalities were grouped within the biome that had predominance of territorial footprint (Table 1) using AutoCAD 2013 for this. This criterion was used because four of the six cities studied are occupied by two or more biomes (Figure 1). Thus, honey samples were collected in the Amazon biome in the municipalities of Alta Floresta and Marcelândia in the Cerrado in Comodoro and Nossa Senhora do Livramento and the Pantanal in Cáceres and Poconé.

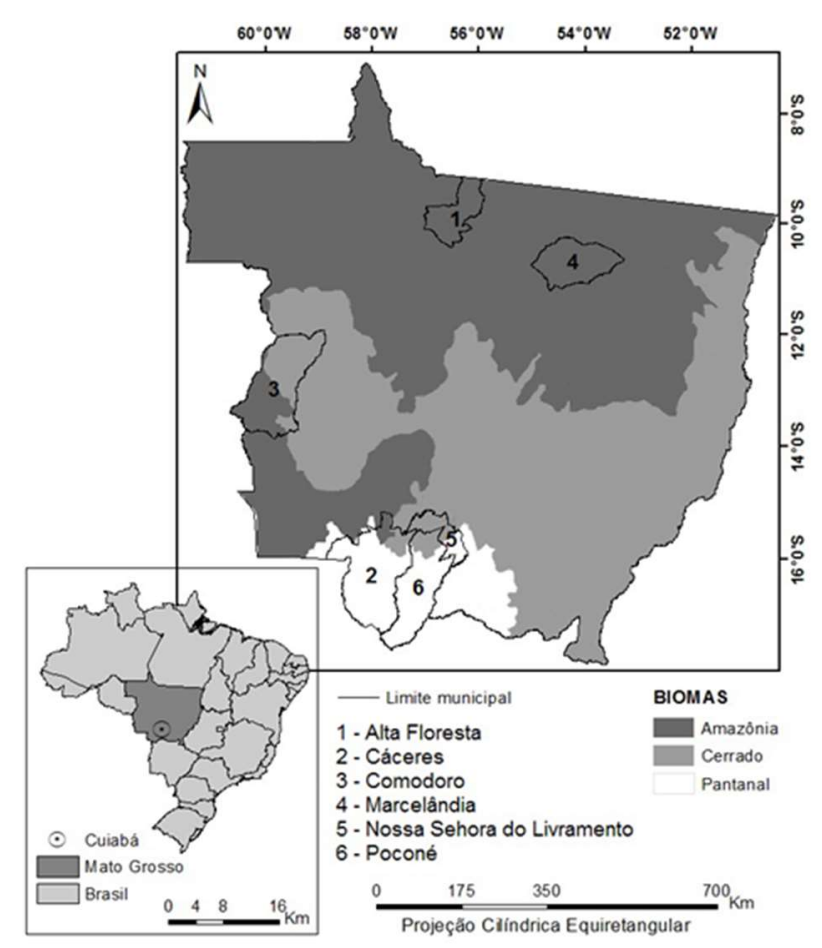

Figure 1: Mato Grosso State municipalities selected to collect honey spread across biomes 
These cities were selected because they are the largest state producers (FERREIRA, 2014; IBGE, 2013), or for being part of a Local Productive Arrangement (CBA, 2013).

Amazon occupies an area of $480.215 \mathrm{~km}^{2}$ in Mato Grosso, characterized by different physiognomic aspects, with presence of palm trees and lianas, humid climate without dry season, with rainfall well distributed throughout the year and high temperatures (IBGE, 2013).

Cerrado occupies an area of $354.823 \mathrm{~km}^{2}$ in Mato Grosso, characterized by vegetation of Savannah, with more than 6500 cataloged plants; the weather is warm, semi-humid and has two distinct seasons: rainy summer and dry winter (IBGE, 2013).

Pantanal occupies a territory of $60.885 \mathrm{~km}^{2}$ in the state, has opened vegetation like the Cerrado, but shows parts of rainforests and extensions of the Amazon ecosystem. Its location in a depression favors seasonal flooding during the rainy summer, when the flood (IBGE, 2013).

Table 1. Predominant biome in the cities due to territorial footprint of Amazon, Cerrado and Pantanal biome in the six municipalities selected for the study.

\begin{tabular}{|c|c|c|c|c|}
\hline \multirow{2}{*}{ Municipalities } & \multicolumn{3}{|c|}{$\%$ municipalities biome } & \multirow{2}{*}{ Predominance } \\
\hline & Amazon & Cerrado & Pantanal & \\
\hline Alta Floresta & 100 & 0.0 & 0.0 & Amazon \\
\hline Cáceres & 5.93 & 8.97 & 85.10 & Pantanal \\
\hline Comodoro & 43.88 & 56.12 & 0.0 & Cerrado \\
\hline Marcelândia & 100 & 0.0 & 0.0 & Amazon \\
\hline Nossa Senhora do Livramento & 0.0 & 63.95 & 36.05 & Cerrado \\
\hline Poconé & 0.0 & 15.74 & 84.26 & Pantanal \\
\hline
\end{tabular}

Honeys used in the study were from the 2012/2013 crop, harvested between July and October, acquired directly with the beekeepers and samples stored in amber bottles under refrigeration.

\section{Microorganisms}

The antibacterial activity was evaluated against bacterial strains from the American Type Culture Collection (ATCC): Staphylococcus aureus (ATCC 25923), Streptococcus pyogenes (ATCC NEWP 0015), Escherichia coli (ATCC 25922), Salmonella typhimurium (ATCC NEWP 0028) and Shigella flexneri (ATCC NEWP 0122).

\section{Physicochemical characteristics}

The determination of phenolic and flavonoid content, reducing sugars, apparent sucrose, insoluble solids, $\mathrm{pH}$, free acidity, diastase activity, electrical conductivity, ashes and the reaction of Lugol were carried out in the Laboratory of the Center for Studies in Beekeeping (CETApis), Campus Cáceres at the University of Mato Grosso (UNEMAT).

The determination of moisture, color, HMF, Fiehe and Lund reactions, glucose and fructose were performed in Food Analysis Laboratory in the Department of Food and Experimental Nutrition, Faculty of Pharmaceutical Science School, University of São Paulo (FCF/ USP).

Moisture of honey was determined by refractive method with the aid of Abbe refractometer and Chataway Table (AOAC, 1990). Reducing sugars and apparent sucrose were quantitated by titration of Fehling 
Solutions A and B (CAC, 2015). Insoluble solids content was determined by the weight of the residue remaining wash sample (CAC, 2015).

Electrical conductivity was determined with the aid of conductivity, taking account of the fact that the higher the ash content and acidity in honey, the higher the resulting conductivity (VORWOHL et al., 1964). Ash content was calculated by gravimetric method to quantify the organic substances not subjected to high temperatures in a muffle which volatilization (CAC, 2015).

Free acidity was determined by simple titration of honey solution with a solution of $0.05 \mathrm{~N}$ sodium hydroxide at pHmeter until pH 8.5 (AOAC, 1990). The optimal pH range of honey is between 3.2 and 4.5 (BERA, 2004). For the quantitative determination of hydroxymethylfurfural (HMF) it was used a high Diastase activity was based on the Schade procedure, which incubate a buffered starch solution using spectrophotometric method (CAC, 2015).

Honey color analysis was performed by colorimetry using the colorimeter "C 221 Honey color analyzer" brand Hanna. The result obtained on the device was compared to the Pfund scale in mm (ALMEIDAMURADIAN et al., 2013; LANARA, 1981).

Lund reaction was based on natural protein precipitation of honey by tannic acid (IAL, 2005; ALMEIDA-MURADIAN et al., 2008). Fiehe qualitative reaction indicate the presence of HMF. Lugol colorimetric reaction indicate the addition of commercial glucose in honey (IAL, 2005; ALMEIDA-MURADIAN et al., 2008). Analysis of glucose and fructose were performed by HPLC (BOGDANOV ET AL., 1997).

\section{Total phenolic and flavonoid content}

For the determination of total phenolic content, it was used the Folin-Ciocalteu method (SINGLETON et al., 1985). An aliquot of $100 \mu \mathrm{L}$ of aqueous solution of honey to $0.2 \mathrm{~g} / \mathrm{mL}$ was mixed with $0.5 \mathrm{ml}$ of FolinCiocalteu and $1.5 \mathrm{~mL}$ of sodium carbonate $20 \% \mathrm{w} / \mathrm{v}$ and the volume was completed with distilled water to 10 $\mathrm{mL}$. The absorbance was read at $765 \mathrm{~nm}$. The assay was performed in triplicate, with the average in $\mathrm{mg}$ of gallic acid equivalents (GAE)/100 g of honey. The reading of the data was extrapolated into a standard analytical curve of gallic acid $(r=0.99)$.

Total flavonoid content was determined using adapted methods (MEDA et al., 2005), with an aliquot of $3 \mathrm{~mL}$ of honey solution in methanol: water (1:1) at a concentration of $500 \mathrm{mg} / \mathrm{ml}$ was mixed with $3 \mathrm{~mL}$ of $2 \%$ methanolic solution of hydrated aluminum chloride (Vetec). After 30 minutes rest, the absorbances were read at a wavelength of $415 \mathrm{~nm}$ against the blank consisting of $3 \mathrm{~mL}$ of methanol. The data were extrapolated into a standard analytical curve of quercetin in methanol $(r=0.99)$.

\section{Antibacterial activity}

The determination of the antibacterial activity of honey was performed using the disk diffusion method (MDD), established as standard by the National Committee for Clinical Laboratory Standards (NCCLS, 2003), and the minimum active dilution (MAD) was estimated.

The honeys were tested at concentrations of $5 \%, 12.5 \%, 25 \%, 50 \%, 75 \%(\mathrm{w} / \mathrm{v})$ and pure honey. The 
microorganisms grown on Mueller Hinton Agar (Staphylococcus aureus and Escherichia coli), Mueller Hinton Agar supplemented with $5 \%$ defibrinated sheep blood in anaerobic environment produced by the anaerobic system Anaerobac - Probac Brazil (Streptococcus pyogenes) and Salmonella-Shigella Agar (Salmonella thypimurim and Shigella flexneri) poured into Petri dishes (NCCLS, 2005).

A suspension of the microorganism to $10^{6}$ McFarland was spread on the plates (NCCLS, 2005), and immediately thereafter, $10 \mu \mathrm{L}$ of honey solutions were added on paper discs.

As a positive control it was used commercial discs of antibiotics Oxacillin (1 $\mu \mathrm{g})$ and Amoxicillin (10 $\mu \mathrm{g})$ for Staphylococcus aureus and Streptococcus pyogenes (SCALABRIN et al., 2003; CRUVINEL et al., 2011), Amoxicillin and Ciprofloxacin $(5 \mu \mathrm{g})$ for Escherichia coli (ZANATTA et al., 2004), Ciprofloxacin and Azithromycin $(15 \mu \mathrm{g})$ for Salmonella typhimurium, and Amoxicillin and Azithromycin for Shigella flexneri (TESSMANN et al., 2008; MESQUITA et al., 2009).

An artificial honey solution ( $3 \mathrm{~g}$ of sucrose, $35 \mathrm{~g}$ of fructose and $45 \mathrm{~g}$ of glucose in $17 \mathrm{~g}$ of sterile deionized water) was tested to determine whether the inhibitory effects linked to content sugar of honey (MERCÊS et al., 2013).

The reading of the antibacterial activity was performed after 24 and $48 \mathrm{~h}$ incubation at a temperature of $37^{\circ} \mathrm{C}$ (OSTROSKY et al., 2008). The antibacterial activity was measured by the diameter $(\mathrm{mm})$ of inhibition zone (halo) around the disks, using a digital caliper (FERRONATTO et al., 2007).

\section{Data analysis}

The physicochemical characteristics were analyzed using descriptive statistics, with the mean and standard deviation of the traits.

Total phenolic and flavonoids content between honeys from different geographical origins was tested with analysis of variance (ANOVA) for geographical origin with six levels the statistical model composed by total phenolic content as the dependent variable and the origin as an independent variable. The statistical model was simplified to three levels, testing the geographic origin for the three biomes (Amazon, Cerrado and Pantanal) as an independent variable, at 5\% significance level. The same statistical model was used for total flavonoids.

The contrast test was used to group the geographical origin levels from the average of total phenolics and flavonoids of honey ( $p>0.05$ ). Total phenolics data were transformed to logarithm and total flavonoids to square root to adjust the distribution Normal errors.

To test the relationship of the color of honey with phenolic and flavonoid content, data were submitted to Spearman correlation analysis to be an analysis that does not relate cause and effect of the variables included in the statistical model, removing the dependency between them and facilitating the interpretation of the relationship. The statistical model for correlation analysis was used to compare the color intensity of honey $(\mathrm{mm})$ and the phenolic content. The same statistical model was used to flavonoids. The Spearman correlation is suitable for distribution of non-normal errors.

The minimum active dilution of each geographical origin honey was calculated by linear regression, 
a statistical model formed by the zone of bacterial inhibition as the dependent variable and honey concentrations as an independent variable.

The minimum active dilution (MAD) honey for Staphylococcus aureus between honey from different geographical origins were tested using analysis of variance (ANOVA), the Kruskal-Wallis type. This analysis was used because the data was not normal. The statistical model has the MAD as the dependent variable and the source municipalities as an independent variable at 95\% significance level.

The minimum active dilution of honey for Escherichia coli and Salmonella tythimurium between honeys of different geographical origins were tested with analysis of variance (ANOVA) to geographical origin in six levels in the statistical model composed of MAD as the dependent variable and municipalities' source as an independent variable. Means were compared using Tukey mean test with the minimum level of statistical significance of $p<0.05$. The Escherichia coli data were transformed to square roots for adjusting the errors from Normal distribution.

The inhibition zones of antibiotics on bacteria were described as the mean and standard deviation of repetitions.

The Shapiro-Wilk test was used to check the fit of the distribution Normal errors. The analyses were performed with $\mathrm{R}$ software ( $\mathrm{R}$ version 3.0.3, 2014).

\section{RESULTS AND DISCUSSION}

\section{Physicochemical characteristics}

Moisture content of evaluated honey in this study ranged from 13.6 to $16.8 \%$, averaging $15.2 \%$ (Table 2), all samples are in accordance with the pattern of $20 \%$ recommended by the Brazilian and international legislation (BRASIL, 2000; CAC, 2001). These results are like those found for honeys from São Paulo, who had moisture content between 16.68 to 18.13\% (CANO et al., 2001; PONTARA et al., 2012).

Mato Grosso honey samples had moisture content exceeding 18 \% (FERREIRA, 2014; LONGO, 2013), unlike the present study, which indicates that beekeepers have adequate management, improving the quality of Mato Grosso honey. The moisture content was related with honey harvest period (ALVAREZ-SUAREZ et al., 2010). Honey from São Paulo was collected during the dry season as well as samples of this work.

The concentration of reducing sugars from Mato Grosso honeys ranged from 66.25 to $89.23 \%$ with an average of $74.39 \%$ (Table 2), all samples are in accordance with the standard stablished by the Brazilian legislation (minimum 65\%) (BRASIL, 2000), and international recommendation (minimum 60\%) (CAC, 2001). These results are close to those observed in honey produced in native vegetation sites in Paraná (67.13 to 72.04\%) (ALVES et al., 2011), and in honey produced in Ethiopia (from 67.79 to 74.62\%) (BELAY et al., 2013). The sugars are the major components of honey, including about $95 \%$ by dry weight of the honey (KÜçÜK et al., 2007). 
Table 2. Physicochemical characteristics of Apis mellifera honey from Amazon, Cerrado and Pantanal of Mato Grosso, Brazil, 2014, expressed as mean and standard deviation (SD), according to the national and international quality standards

\begin{tabular}{|c|c|c|c|}
\hline Physicochemical characteristics & Mean $\pm \mathrm{SD}(\mathrm{N}=18)$ & BRAZIL $^{a}$ & Codex $^{b}$ \\
\hline Moisture (\%) & $15.2 \pm 0.95$ & Max. 20 & Max. 20 \\
\hline Reducing sugars (\%) & $74.39 \pm 6.01$ & Min. 65 & Min. 60 \\
\hline Apparent sucrose (\%) & $2.41 \pm 3.18$ & Max. 6 & Max. 5 \\
\hline Insoluble solids (\%) & $0.10 \pm 0.07$ & Max. 0.1 & Max. 0.1 \\
\hline Electrical conductivity $\left(\mu \mathrm{S} . \mathrm{cm}^{-1}\right)$ & $433.67 \pm 193.6$ & - & Max. 800 \\
\hline Ashes (\%) & $0.24 \pm 0.20$ & Max. 0.6 & - \\
\hline Free acidity (mEq. $\mathrm{kg}^{-1}$ ) & $38.27 \pm 11.69$ & Max. 40 & Max. 50 \\
\hline $\mathrm{HMF}\left(\mathrm{mg} \cdot \mathrm{kg}^{-1}\right)$ & $34.69 \pm 35.05$ & Max. 60 & Max. 80 \\
\hline Diastase (Un. Goethe/ g of honey) & $50.65 \pm 3.55$ & Min. 3 & Min. 8 \\
\hline Fiehe reaction (positive) & 11 samples & - & - \\
\hline Lund reaction $(\mathrm{mL})$ & $0.81 \pm 0.45$ & - & - \\
\hline Lugol reaction (positive) & 0 samples & - & - \\
\hline Glucose (\%) & $39.09 \pm 3.82$ & - & - \\
\hline Fructose (\%) & $48.07 \pm 4.08$ & - & - \\
\hline
\end{tabular}

Legend: ( - ): not required standard; HMF: hydroxymethylfurfural; Max.: maximum; Min.: minimum; SD: standard deviation.

avalue recommended by Brazilian legislation (BRASIL, 2000).

bValue recommended by the Codex Alimentarius (CAC, 2001).

The apparent sucrose showed values between zero and $12.15 \%$, with an average of $2.41 \%$ (Table 2). Only one sample was out of the standard of the Brazilian legislation (BRASIL, 2000), which stablish a maximum of $6 \%$ and three samples were not in accordance with the maximum of $5 \%$ from international recommendation (CAC, 2001). The higher levels of apparent sucrose (1.98 to 6.22\%) was found in honey samples from Turkey and attributed this to the fact that bees possibly have been fed with sugar syrup in place of nectar (KAHRAMAN et al., 2010), which was not what occurred in this study in Mato Grosso.

The increase of sucrose in honey are due to early crop, when honeycombs are not operculate or even due to addition of sucrose commercial honey (GOMES et al., 2010). This management feature should provide guidance to beekeepers as good beekeeping practices for quality honey production.

Insoluble solid content of the studied honey varied from 0.0085 to $0.24 \%$ (Table 2 ) and six samples were out of the Brazilian standard (BRASIL, 2000; CAC, 2001), which limits to a maximum of $0.1 \%$. This result was like honey from Ethiopia who found levels of up to $0.38 \%$ of insoluble solids (BELAY et al., 2013). The presence of impurities in honey (wax, pollen, honeycomb debris, dirt and bees' particles) may be attributed to the lack of knowledge or lack of quality in the product extraction, processing and packaging (BELAY et al., 2013).

Electrical conductivity varied 147 to $901 \mu \mathrm{S} . \mathrm{cm}^{-1}$, with an average of $433.67 \mu \mathrm{S} . \mathrm{cm}^{-1}$ (Table 2) and only one sample was out of the international standard which recommends a maximum of $800 \mu \mathrm{S} . \mathrm{cm}^{-1}$ (CAC, 2001). Electrical conductivity is no present in the Brazilian legislation (BRASIL, 2000). Similar values (340 and 1040 $\mu \mathrm{S} . \mathrm{cm}^{-1}$ ) was found for electrical conductivity of Tocantins honey samples (ABADIO FINCO et al., 2010), and this variation related to the $\mathrm{pH}$, acidity, and ash content present in honey.

Apparent sucrose content and electrical conductivity were two characteristics that presented more samples out of the standard for precvious study for honeys from Mato Grosso (FERREIRA, 2014; LONGO, 2013), different from the present study which only one sample was out of the standard. This shows that 
beekeepers are paying attention to achieving the harvest at the right time, avoiding $\mathrm{pH}$ extremely acid and high levels of apparent sucrose.

Ashes average content of the honey was $0.24 \%$, with values from 0.02 to $0.87 \%$ (Table 2). Two of the samples were out of the recommended by the Brazilian legislation (maximum of $0.6 \%$ for floral honey samples) (BRASIL, 2000). The ashes average content allows detecting some irregularities in honey, especially the lack of hygiene and/or filtration after harvesting the honey by beekeepers (VILHENA et al., 1999). The monofloral honey Eucalyptus from São Paulo had more ashes compared with honey of other floral sources (BARTH et al., 2013; FELSNER et al., 2004), indicating that this characteristic may be related to the botanical origin.

Free acidity level of honeys ranged from 23.13 to $59.81 \mathrm{mEq} / \mathrm{kg}$ (Table 2), with eight samples outside of the Brazilian standard (maximum $40 \mathrm{mEq} / \mathrm{kg}$ ) (BRASIL, 2000), but only four samples were out of the international standard (maximum $50 \mathrm{mEq} / \mathrm{kg}$ )ius, 2001) (CAC, 2001). Some authors reported that besides the polinic source, incorrect storage or early harvest can modify the acidity of honey, which can be improved with the use of good practice of beekeeping management (GOMES et al., 2010). Moreover, the environment with high temperature and high humidity promotes the acidification reaction of honey (ALMEIDA-MURADIAN et al., 2007).

The use of honey house together with the number of hives are the most important beekeeping practices to ensure the physicochemical properties of honey, and the number of hives expresses the professionalism of the beekeeper from Baixada Cuiabana and the Pantanal of Mato Grosso, Brazil (LONGO, 2013).

HMF content presented an average of $34.69 \mathrm{mg} . \mathrm{kg}^{-1}$, ranging from 2.56 to $127.28 \mathrm{mg} \cdot \mathrm{kg}^{-1}$, with four samples in disagreement with the Brazilian standard (maximum $60 \mathrm{mg} / \mathrm{kg}$ ) (BRASIL, 2000), and two samples out of the international recommendation (maximum $80 \mathrm{mg} / \mathrm{kg}$ ) (CAC, 2001). The fresh honey does not contain HMF. However, if the honey is subjected to high temperatures (BOGDANOV et al., 2004), inadequate storage conditions or long storage time it begins to show high levels of HMF (SANTOS et al., 2010). In Mato Grosso, predominantly high temperatures throughout the year, it demands greater care with honey conservation.

All samples presented HMF values were in accordance with the Brazilian legislation (minimum of 3 mg. $\mathrm{kg}^{-1}$ ) (BRASIL, 2000), and international recommendation (minimum of $8 \mathrm{mg} \cdot \mathrm{kg}^{-1}$ ) (CAC, 2001). For diastase value, it was obtained an average of $50.65 \mathrm{Un}$. Goethe/g of honey (Table 2). The honey Cuba was within the international standard (13.4 to 33.4 Un. Goethe/g of honey) (ALVAREZ-SUAREZ et al., 2010), and state that this characteristic indicates that honey has quality.

Eleven of the 18 samples showed positive reaction Fiehe. The results of qualitative analysis of HMF to Tocantins honey showed that $25 \%$ of the samples showed a positive response to Fiehe reaction (ABADIO FINCO et al., 2010), indicating poor quality of these honeys for possible tampering or overheating. The results of qualitative HMF of this study were confirmed by quantitative analysis, which found four samples in disagreement with the Brazilian standard and two with the international standard, although all agree 
regarding diastase values, indicating possible overheating of some samples.

For Lund reaction, five of the 18 samples were not in accordance with the recommendation of $0.6 \mathrm{tp}$ $3 \mathrm{~mL}$ (ALMEIDA-MURADIAN et al., 2008; IAL, 2005), with a deposit below $0.6 \mathrm{~mL}$. In honeys from Tocantins, eight samples exceeding the standard value from Lund reaction, suggesting loss or addition of protein substances in product during the processing (COOPER et al., 2010).

All samples showed negative Lugol reaction. The same result was found in honey from Ceará (PAULINO et al., 2009). This test indicates qualitatively the possible adulteration of the honey with commercial glucose.

The honey content of the two sugars in total was found up to $70-95 \%$. The honey samples content in glucose and fructose was determined by HPLC (32.45-43.98\% and 36.76-51.64\%, respectively).

Honey color analysis showed a great variation, extra white (17 mm on the Pfund scale) to amber (100 $\mathrm{mm}$ ), but most of the samples (44\%) were predominated light amber color (50 to $84 \mathrm{~mm}$ ).

$\mathrm{pH}$ average was 3.9, ranging from 3.6 to 4.4, similar with Tocantins' honey which presented $\mathrm{pH}$ between 3.35 and 4.50 (ABADIO FINCO et al., 2010).

\section{Content of total phenolic and flavonoid}

For total phenolic, Amazon honeys studied in this work showed 15.0 to $41.5 \mathrm{mg}$ GAE/100 g of honey ( $x=31.33$ ), Cerrado honeys 17.0 to $59.5 \mathrm{mg}$ of EAG/100 g of honey ( $x=34.08)$ and Pantanal honeys 14.0 to $122.5 \mathrm{mg} \mathrm{GAE} / 100 \mathrm{~g}$ of honey ( $\mathrm{x}=47.92$ ) (Table 3), with no significant difference between the three studied biomes $(p=0.64)$.

Total phenolic content in honey was similar between the source of the municipalities of Alta Floresta, Cáceres and Comodoro $(x=26.67)$, which was grouped by the contrast test $(p=0.68)$, the municipalities of Marcelândia, Nossa Senhora do Livramento and Poconé had similar content $(x=48.89)$ and formed another group $(p=0.24)$.

The Santa Catarina honey was found content of phenolic compounds between 36.37 and $71.69 \mathrm{mg}$ GAE/100 g of from (RIZELIO, 2011). The honey from other countries and different floral origins, and found total phenolic content from 32.59 to $114.74 \mathrm{mg} \mathrm{GAE} / 100$ g of honey (NCCLS, 2003), while a publication related to honey from Pantanal of Mato Grosso do Sul identified levels of total phenolic compounds with an average of 61.52 and $222.03 \mathrm{mg} \mathrm{GAE} / 100 \mathrm{~g}$ of honey, depending on the place of harvest (BERTOLDI et al., 2012). Those results were considerably higher than those of honeys evaluated in this study (BERTOLDI et al., 2012; MEDA et al., 2005).

Table 3. Levels of total phenolics and flavonoids present in honey of Apis mellifera, from Mato Grosso, Brazil, 2014

\begin{tabular}{ccc}
\hline Biome & $\begin{array}{c}\text { Total phenolics * } \\
\text { (mg de GAE/100 g of honey) }\end{array}$ & $\begin{array}{c}\text { Total flavonoids * } \\
\text { (mg de QE/100 g of honey) }\end{array}$ \\
\hline Paney source & $47.92 \pm 37.96$ & $0.26 \pm 0.04$ \\
Cerrado & $34.08 \pm 15.03$ & $0.28 \pm 0.09$ \\
Amazon & $31.33 \pm 11.18$ & $0.27 \pm 0.06$ \\
\hline
\end{tabular}

Legend: GAE: gallic acid equivalent; QE: equivalent quercetin.

*Means in columns do not differ at $5 \%$ by $\mathrm{F}$ test. $\mathrm{N}=18$. 
For total flavonoid content, it was obtained an average of $0.27 \mathrm{mg} \mathrm{QE} / 100 \mathrm{~g}$ of honey for Amazon samples, with the highest concentration of 0.36 and less than $0.19 \mathrm{mg} Q E / 100 \mathrm{~g}$ of honey. The average value obtained for Cerrado honeys was $0.28 \mathrm{mg} \mathrm{QE} / 100 \mathrm{~g}$ of honey, ranging from 0.21 to $0.47 \mathrm{mg} \mathrm{QE} / 100 \mathrm{~g}$ of honey. Pantanal honeys presented an average of $0.26 \mathrm{mg} \mathrm{QE} / 100 \mathrm{~g}$ of honey, ranging from 0.20 to $0.34 \mathrm{mg}$ $\mathrm{QE} / 100 \mathrm{~g}$ of honey (Table 3). These results did not differ significantly between the three studied biomes $(p=0.89)$.

The flavonoid content in honey was similar between the source of the municipalities of Alta Floresta, Cáceres and Comodoro $(x=0.24)$, which was grouped by the contrast test $(p=0.69)$. The municipalities of Marcelândia, Nossa Senhora do Livramento and Poconé had similar content $(x=0.30)$ and formed another group $(p=0.73)$.

Flavonoid content found in the studied honey are lower than those honey of various types, from different countries, and found levels between 0.17 and $8.35 \mathrm{mg} \mathrm{QE} / 100 \mathrm{~g}$ of honey (MEDA et al., 2005).

The phenolic content and total flavonoids were grouped into two levels as the geographical origin of the municipalities. The botanical source of phenolic compounds and flavonoids may be the same, so the grouped municipalities should be similar for the availability of floral resources.

These results suggested that the geographical origin of municipalities, not the biome of origin, influences the content of these metabolites, however there is similarity between the municipalities of Alta Floresta, Cáceres and Comodoro and between Marcelândia, Nossa Senhora do Livramento and Poconé.

The phenolic and flavonoids are responsible for the honey bioactivity. They have antioxidant, antimicrobial, antiviral and anticarcinogenic capacity, generating a beneficial effect on human health, and awakening interest in identification and quantification (KÜÇÜK et al., 2007; RIZELIO, 2011).

The honey color variation depends on the combination of many factors, including the content of phenolic acids and flavonoids (ALVAREZ-SUAREZ et al., 2010; BERETTA et al., 2005). The honey production methods and agricultural practices can also influence the color (ALMEIDA-MURADIAN et al., 2013).

Total phenolic content was positively correlated with the color of honey $(r=0.735, p<0.01$, Table 4 , Figure 2), corroborating the work of Alvarez-Suarez et al. (2010), which found higher total phenolic contents for the amber honey, and lower level for extra white honey. The lighter honey Portugal the phenolic content was lower than in the darkest honey (FERREIRA et al., (2009).

The amber honey (darker color) had higher levels of total flavonoids ( $0.47 \mathrm{mg} Q \mathrm{E} / 100 \mathrm{~g}$ of honey), while extra white honey (lighter color) had the lowest content of flavonoids (0.19 QE mg/100 g of honey). This was confirmed by the positive correlation between color and the quantity of total flavonoids $(r=0.891$, p<0.01, Table 4, Figure 3).

A positive correlation between total flavonoid content and the color of honeys from Cuba was observed, ${ }^{7}$ as the amber honey showed a high flavonoid content and white extra honey very low content. The ratio of increase in the color intensity of honey with the concentration of total phenolics, and flavonoids (MEDA et al., 2005).

A significant positive correlation was found between phenolic content and total flavonoid $(r=0.764$, 
$\mathrm{p}<0.01)$, as well as Cuban honey that the increase of the intensity of color appears to be related to the increased concentration of total flavonoids and phenolic compounds (ALVAREZ-SUAREZ et al., 2010). Thus, the present study results seem to confirm that the contents of these compounds can directly affect the color of honey.

Table 4. Spearman correlation between the color and the total phenolic and flavonoids content of Apis mellifera honey, Mato Grosso, Brazil, 2014

\begin{tabular}{lccc}
\hline Parameters & Color & Phenolic & Flavonoid \\
\hline Color & 1.00 & & \\
Phenolic & $0.73^{* *}$ & 1.00 & 1.00 \\
Flavonoid & $0.89^{* *}$ & $0.76^{*}$ & \\
\hline
\end{tabular}

Legend: ${ }^{*} \mathrm{p}<0.05,{ }^{*} \mathrm{p}<0.01 . \mathrm{N}=18$

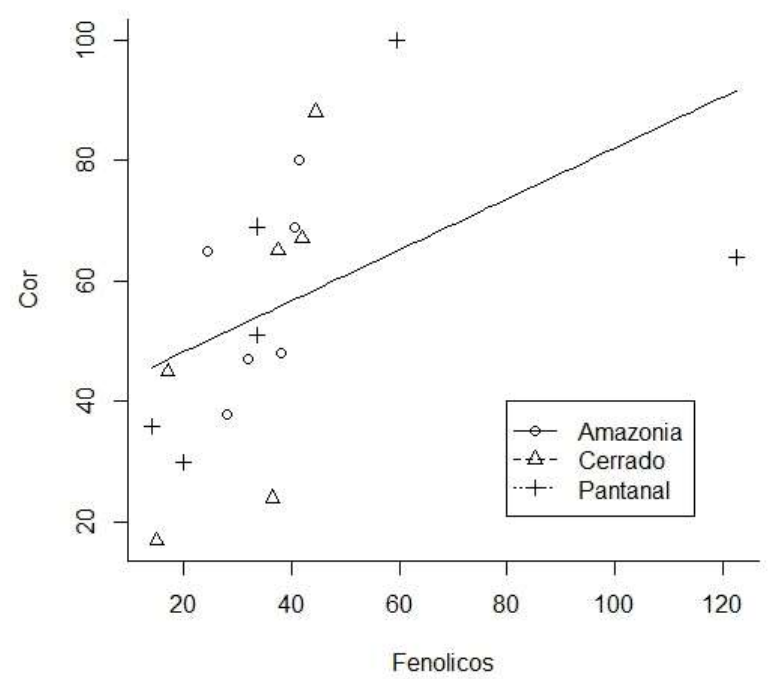

Figure: 2. Relationship of color (in mm Pfund scale) and total phenolic content (mg GAE/100 g of honey) of honey from the Amazon, Cerrado and Pantanal of Mato Grosso, Brazil, 2014. (Spearman correlation: $r=0.73, p<0.01$ )

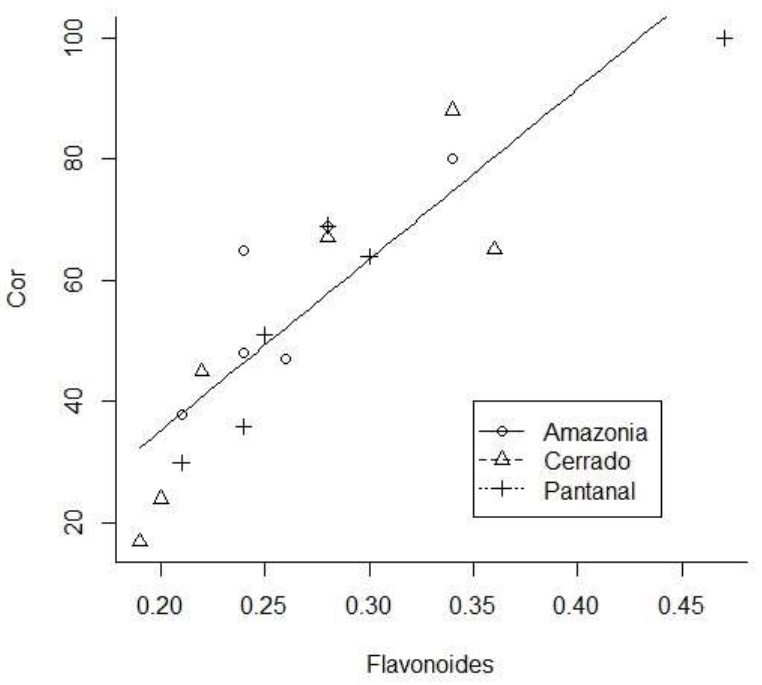

Figure 3: Relationship of color (in mm Pfund scale) and total flavonoid content ( $\mathrm{mg} Q \mathrm{Q} / 100 \mathrm{~g}$ of honey) of Brazilian honey from the Amazon, Cerrado and Pantanal area of Mato Grosso, 2014. (Spearman correlation: $r=0.89, p<0.01$ ) 


\section{Antibacterial activity}

The antibacterial activity of Mato Grosso honey studied in this work presented minimum active dilution for the bacteria Staphylococcus aureus, Escherichia coli and Salmonella typhimurium of $44.58 \% \mathrm{w} / \mathrm{v}$ (Table 5). The minimum active dilution for each bacterium did not differ between geographical origins of honey (Table 5). Honey showed no antibacterial activity against strains Streptococcus pyogenes and Shigella flexneri, with no inhibition zone formation around the discs with treatment.

The minimum active dilution of $44.58 \% \mathrm{w} / \mathrm{v}$ was considered not effective for Staphylococcus aureus ompared the Cuban honeys with MAD 4.02\% v / v (deemed sensitive) (ALVAREZ-SUAREZ et al., 2010), and MAD 7.96 and $8.02 \%$ v/v for Escherichia coli and Bacillus subtilis, respectively (considered moderate sensitive).

The estimated Staphylococcus aureus zone of inhibition that for every $\mathrm{mm}$ was required a concentration of $15.5 \% \mathrm{w} / \mathrm{v}$ in Greek honey (VOIDAROU et al., 2011), concentration three times lower than the concentration found for Mato Grosso honey. In another study, the minimum active dilution of Manuka honey and pasture honey against Staphylococcus coagulase-negative isolates from New Zealand patients ranged from 2.7 to $5.0 \%$ v/v (FRENCH et al., 2005), concentration nine times lower than that presented by Mato Grosso honey.

The artificial honey did not form inhibition zone for any of the tested microorganisms, Manuka honey and Ulmo honey inhibited the microorganisms tested more extensively than the artificial honey (SHERLOCK et al., 2010). The idea that sugar is solely responsible for the honey antibacterial activity was not validated (HANNAN et al., 2009), and claim that the antibacterial effect of natural honey is not connected only with the high osmolarity, because in their study, the artificial honey inhibited the bacteria tested at higher concentrations than the natural honey.

Table 5. Minimum active dilution (MAD \% w/v) of Apis mellifera honey, Mato Grosso, Brazil, 2014

\begin{tabular}{lccc}
\hline Bacteria & MAD of honey (mean \pm SD) $)^{++}$ & $\mathrm{R}^{2}$ & $\mathrm{p}^{*}$ \\
\hline Staphylococcus aureus & $44.58 \pm 141.42$ & 0.67 & $0.69^{\mathrm{a}}$ \\
Escherichia coli & $44.58 \pm 99.84$ & 0.84 & $0.98^{\mathrm{b}}$ \\
Salmonella tythimurium & $44.58 \pm 321.29$ & 0.96 & $1.00^{\mathrm{b}}$ \\
\hline
\end{tabular}

${ }^{++}$Minimum active dilution of honey in $\% \mathrm{w} / \mathrm{v}$, resulting in a $1 \mathrm{~mm}$ zone of inhibition.

*ANOVA for comparison of the probability of minimum active dilution of honey between geographical origins by Kruskal-Wallis test for Staphylococcus aureus a and the $\mathrm{F}$ test for Escherichia coli ${ }^{\mathrm{b}}$ and Salmonella tythimurium. $\mathrm{N}=18$.

Bacteria were sensitive to commercially antibiotics, with inhibition zone average of $33.26 \mathrm{~mm}$ for Staphylococcus aureus, $27.27 \mathrm{~mm}$ for Streptococcus pyogenes, $22.61 \mathrm{~mm}$ for Escherichia coli, $22.09 \mathrm{~mm}$ for Salmonella typhimurium and $24.88 \mathrm{~mm}$ for Shigella flexneri.

The antimicrobial activity of Cuban honey was related to differences in the profile of phenolic and flavonoids compounds (quercetin and gallic acid, respectively), because the honey that showed higher phenolic and flavonoid content showed higher antimicrobial activity (ALVAREZ-SUAREZ et al., 2010). The high antimicrobial activity of honey from Portugal was associated to the high content of phenolics and flavonoids (quercetin and caffeic acid, respectively) (MIGUEL et al., 2013).

The honey produced in other countries may have different antimicrobial activity of honey produced 
in Brazil, more specifically of Mato Grosso honey, because there can be great variation in the profile of therapeutic components (phenolics and flavonoids) depending on their geographical origin (ESTEVINHO et al., 2012; MOLAN, 2002).

Honey from Amazon, Cerrado and Pantanal of Mato Grosso need to be studied in search of other different phenolic compounds of gallic acid investigated in this work, such as protocatechuic acid, phydroxybenzoic acid, caffeic acid, chlorogenic acid, vanillic acid, p-coumaric acid, benzoic acid, cinnamic acid and ellagic acid, identified in Portuguese honey (ESTEVINHO et al., 2008). Other flavonoids different from quercetin should be investigated in Mato Grosso honey, such as naringenin, kaempferol, apigenin, pinocembrine and chrysin, identified in Portuguese honey (ESTEVINHO et al., 2008). These phenolic and flavonoids compounds may be associated with antimicrobial activity attributed to honey (ALADI et al., 2003; YAO et al., 2003).

The methodological limitations of this study were due to antimicrobial activity by disk diffusion and not by microdilution broth, which is stronger in the search for pharmacological interest, and the representativeness of the six municipalities in Mato Grosso state in relation to the universe one hundred forty-one municipalities.

\section{CONCLUSION}

Mato Grosso has potential to floral honey production, even if the physicochemical quality of the product needs to be adequate, especially in relation to apparent sucrose, insoluble solids, ashes and free acidity.

The darker honey has a higher total phenolic and flavonoid content, although they are not indicated in the control of Staphylococcus aureus, Streptococcus pyogenes, Escherichia coli, Salmonella typhimurium and Shigella flexneri.

\section{REFERENCES}

ABADIO FINCO, F. D. B.; MOURA, L. L.; SILVA, I. G.. Propriedades físicas e químicas do mel de Apis mellifera $\mathrm{L}$. Ciência e Tecnologia de Alimentos, Campinas, v.30, n.3, p.706-712, 2010. DOI: http://doi.org/10.1590/S0101$\underline{20612010000300022}$

ALJADI, A. M.; YUSOFF, K. M.. Isolation and identification of phenolic acids in Malaysian honey with antibacterial properties. Turkish Journal of Medicine and Sciences, v.33, p.229-236, 2003. DOI: http:// doi.org/10.1155/2014/737490

ALMEIDA-MURADIAN, L. B.; MATSUDA, A. H.. Physicochemical parameters of Amazon melipona honey. Química Nova, v.30, n.3, p.707-708, 2007. DOI: http://doi.org/10.1590/\$0100-40422007000300033

ALMEIDA-MURADIAN, L. B.; STRAMM, K. M.; ESTEVINHO, L. M.. Efficiency of the FT-IR ATR spectrometry for the prediction of the physicochemical characteristics of Melipona subnitida honey and study of the temperature's effect on those properties. International Journal of Food
Science and Technology, p.1-8, 2013. DOI: http://doi.org/10.1111/ijfs.12297

ALMEIDA-MURADIAN, L. B.; STRAMM, K. M.; HORITA, A.; BARTH, O. M.; FREITAS, A. S.; ESTEVINHO, L. M..

Comparative study of the physicochemical and palynological characteristics of honey from Melipona subnitida and Apis mellifera. International Journal of Food Science and Technology, v.48, p.1698-1706, 2013. DOI: http://doi.org/10.1111/ijfs.12140

ALMEIDA-MURADIAN, L. B.; BERA, A.. Manual de controle de qualidade do mel. $1^{\text {th }}$ ed. São Paulo: Apacame, 2008.

ALVAREZ-SUAREZ, J. M.; TULIPANI, S.; DÍA, D.; ESTEVEZ, Y.; ROMANDINI, S.; GIAMPIERI, F.; DAMIANI, E.; ASTOLFI, P.; BOMPADRE, S.; BATTINO, M.. Antioxidant and antimicrobial capacity of several monofloral Cuban honeys and their correlation with color, polyphenol content and other chemical compounds. Food and Chemical Toxicology, v.48, p.2490-2499, 2010. DOI: http://doi.org/10.1016/i.fct.2010.06.021 
ALVES, E. M.; SEREIA, M. J.; TOLEDO, V. A. A. S.; MARCHINI, L. C.; NEVES, C. A.; TOLEDO, T. C. S. O. A.; ANACLETO, D. A.. Physicochemical characteristics of organic honey samples of africanized honeybees from Parana River island. Ciência e Tecnologia de Alimentos, Campinas, v.31, p.635-639, 2011. DOI: http://doi.org/10.1590/S0101-20612011000300013

AOAC. Association of Official Analytical Chemists. Official methods of analysis of the Association of Official Analytical Chemists, AOAC: Arlington: 500p. 1990.

AZEREDO, L. C.; AZEREDO, M. A. A.; DUTRA, V. M. L.. Protein contents and physicochemical properties in honey samples of Apis mellifera of different floral origins. Food Chemistry, v.80, p.249-254, 2003. DOI: http://doi.org/10.1016/S0308$\underline{8146(02) 00261-3}$

BALTRUŠAITYTĖ, V.; VENSKUTONIS, P. R.; ČEKSTERYTĖ, V.. Radical scavenging activity of different floral origin honey and beebread phenolic extracts. Food Chemistry, v.101, n.2, p.502-514, 2007. DOI:

http://doi.org/10.1016/j.foodchem.2006.02.007

BARTH, O. M.; FREITAS, A. S.; SOUSA, G. L.; ALMEIDAMURADIAN, L. B.. Pollen and physicochemical analysis of Apis and Tetragonisca (Apidae) honey. Interciência, Caracas, v.38, n.4, p.280-285, 2013. DOI: http://doi.org/0378$\underline{1844 / 13 / 04 / 280-06}$

BELAY, A.; SOLOMON, W. K.; BULTOSSA, G.; ADGABA, N.; MELAKU, S.. Physicochemical properties of the Harenna forest honey, Bale, Ethiopia. Ethiopia Food Chemistry, v.35, p.3386-3392, 2013.

DOI: http://doi.org/10.1016/j.foodchem.2013.06.035

BERA, A.. Composição físico-química e nutricional do mel adicionado com própolis. Dissertação (Mestrado em Ciência dos Alimentos) - Universidade de São Paulo, São Paulo, 2004.

BERA, A.; ALMEIDA-MURADIAN, L. B.. Mel com própolis: considerações sobre a composição e rotulagem. Revista do Instituto Adolfo Lutz, v.64, n.1, p.117-121, 2005.

BERETTA, G.; GRANATA, P.; FERRERO, M.; ORIOLI, M.; FACINO, R. M.. Standardization of antioxidant properties of honey by a combination of spectrophotometric/fluorimetric assays and chemometrics. Analytica Chimica Acta, v.533, p.185-191, 2005. DOI:

http://doi.org/10.1016/j.aca.2004.11.010

BERTOLDI, F. C.; GONZAGA, L. V.; FETT, R.; DOS REIS, V. D. A. Avaliação da atividade antioxidante e determinação de compostos fenólicos totais de méis produzidos no Pantanal. Evidência, Joaçaba, v.12, n.2, p.155-164, 2012.

BLAIR, S. E.; COKCETIN, N. N.; HARRY, E. J.; CARTER, D. A.. The unusual antibacterial activity of medical-grade Leptospermum honey: antibacterial spectrum, resistance and transcriptome analysis. European Journal of Clinical Microbiology, v.28, p.1199-208, 2009. DOI: http://doi.org/10.1007/s10096-009-0763-z

BOGDANOV, S.; RUOFF, K.; ODDO, L. P.. Physico-chemical methods for the characterisation of unifloral honeys: $A$ review. Apidologie, v.35, p.4-17, 2004. DOI:

http://doi.org/10.1051/apido:2004047

BOGDANOV, S.; MARTIN, P.; LÜLLMANN, C.. Harmonised methods of the European Honey Commission. Apidologie, extra issue, p.1-59, 1997.

BRASIL. Instrução Normativa no 11, de 20 de outubro de 2000. Regulamento Técnico de Identidade e Qualidade do Mel. Diário Oficial da República Federativa do Brasil. Brasília: MAPA, 2000

CAC, Codex Alimentarius Commission. Recommended methods of analysis and sampling - Codex Stan 234-1999. $38^{\text {th }}$ ed., CODEX Alimentarius: FAO, 2015.

CAC, Codex Alimentarius Commission. Standard for honey Codex standard 12-1981, Revised ed., CODEX Alimentarius: FAO, 2001.

CANO, C. B.; FELSNER, M. L.; MATOS, J. R.; BRUNS, R. E.; WHATANABE, H. M.; ALMEIDA-MURADIAN, L. B. Comparison of methods for determining moisture content os Citrus and Eucalyptus Brazilian honeys by refractometry. Journal of foof composition and analysis, v.14, p.101-109, 2001. DOI: http://doi.org/10.1006/jfca.2000.0951

COOPER, R. A.; JENKINS, L.; HENRIQUES, A. F. M.; DUGGAN, R. S.; BURTON, N. F.. Absence of bacterial resistance to medical-grade manuka honey. European Journal of Clinical Microbiology, v.29, p.1237-1241, 2010. DOI: http://doi.org/10.1007/s10096-010-0992-1

CRUVINEL, A. R.; SILVEIRA, A. R.; SOARES, J. S.. Perfil antimicrobiano de Staphylococcus aureus isolado de pacientes hospitalizados em UTI no Distrito Federal. Cenarium Pharmacêutico, v.4, n.4, p.1984-3380, 2011

DALLEMOLE, D.; FARIA, A. M. M.; AZEVEDO-JUNIOR, W. C.; GOMES, V. M.. O arranjo produtivo local da apicultura de Mato Grosso: evolução recente e necessidade de ajustes. Revista de Estudos Sociais, v.2, p.181-197, 2010.

ESCUREDO, O.; SILVA, L.; VALENTAO, P.; SEIJO, M. C.; ANDRADE, P.. Assessing Rubus honey value: Pollen and phenolic compounds content and antibacterial capacity. Food Chemistry, v.130, p.671-678, 2012. DOI: http://doi.org/10.1016/j.foodchem.2011.07.107

ESTEVINHO, L. M.; FEÁS, X.; SEIJAS, J. A.; VÁZQUEZ-TATO, M. $P$.. Organic honey from Trás-Os-Montes region (Portugal): chemical, palynological, microbiological and bioactive compounds characterization. Food and Chemical Toxicology, v.50, n.2, p.258-264, 2012. DOI: http://doi.org/10.1016/j.fct.2011.10.034

ESTEVINHO, L.; PEREIRA, A. P.; MOREIRA, L.; DIAS, L. G.; PEREIRA, E.. Antioxidant and antimicrobial effects of phenolic compounds extracts of Northeast Portugal honey. Food and Chemical Toxicology, v.46, p.3774-3779, 2008. DOI: http://doi.org/10.1016/j.fct.2008.09.062

FELSNER, M. L.; CANO, C. B.; BRUNS, R. E.; WATANABE, H. M.; ALMEIDA-MURADIAN, L. B.; MATOS, J. R..

Characterization of monofloral honeys by ash contents through a hierarchical design. Journal of Food Composition and Analysis, v.17, p.737-747, 2004. 
FERREIRA, I.; AIRES, E.; BARREIRA, J. C. M.; ESTEVINHO, L.. Antioxidant activity of Portuguese honey samples: different contributions of the entire honey and phenolic extract. Food Chemistry, v.114, p.1438-1443, 2009. DOI: http://doi.org/10.1016/j.foodchem.2008.11.028

FERREIRA, J. O.. A influência da cobertura vegetal e do uso da terra dos biomas Amazônia, Cerrado e Pantanal na apicultura no Mato Grosso. Dissertação (Mestrado em Ciências Ambientais) - Universidade do Estado de Mato Grosso, Cáceres, 2014.

FERRONATTO, R.; MARCHESAN, E. D.; PEZENTI, E.; BEDNARSKI, F.; ONOFRE, S. B.. Atividade antimicrobiana de óleos essenciais produzidos por Baccharis dracunlifolia D. C. e Baccharis uncinella D. C. (Asteraceae). Revista Brasileira de Farmacognosia, v.17, n.2, p.224-230, 2007. ISSN 0102$695 X$

FRENCH, V. M.; COOPER, R. A.; MOLAN, P. C.. The antibacterial activity of honey against coagulase-negative staphylococci. Journal of Antimicrobial Chemotherapy, v.56, p.228-231, 2005. DOI: http://doi.org/10.1093/jac/dki193

GOMES, S.; DIAS, G. L.; MOREIRA, L. L.; RODRIGUES, P.; ESTEVINHO, L.. Physicochemical, microbiological and antimicrobial properties of commercial honeys from Portugal. Food Chemistry, v.48, p.544-548, 2010. DOI: http://doi.org/10.1016/i.fct.2009.11.029

HANNAN, A.; BARKAAT, M.; USMAN, M.; GILANI, W. A.; SAMI, W.. In Vitro Antibacterial Activity of Honey Against Clinical Isolates of Multi-Drug Resistant Typhoidal Salmonellae. Pakistan Journal of Zoology, v.41, n.1, p.1-6, 2009. DOI: http://doi.org/0030-9923/2009/0001-0001

IAL, Instituto Adolfo Lutz. Métodos físico-químicos para análise de alimentos. 4eed., Agência Nacional de Vigilância Sanitária: Brasília, 2005.

IBGE. Instituto Brasileiro de Geografia e Estatística, 2013.

JENKINS, R.; WOOTTON, M.; HOWE, R.; COOPER, R.. Susceptibility to manuka honey of Staphylococcus aureus with varying sensitivities to vancomycin. International Journal of Antimicrobial Agents, v.40, n.1, p.88-9, 2012. DOI: http://doi.org/10.1016/i.ijantimicag.2012.03.014

KAHRAMAN, T.; BUYUKUNAL, S. K.; VURAL, A.; ALTUNATMAZ, S. S.. Physico-chemical properties in honey from different regions of Turkey. Food Chemistry, v.123, p.41-44, 2010. DOI: 10.1016/j.foodchem.2010.03.123

KHALIL, M. I.; ALAM, N.; MONIRUZZAMAN, M.; SULAIMAN, S. A.; GAN, S. H.. Phenolic acid composition and antioxidant properties of Malaysian honeys. Journal of Food Science, v.76, p.C921-C928, 2011. DOI:

http://doi.org/10.1111/j.1750-3841.2011.02282.x

KÜÇÜK, M.; KOLAYL, S.; KARAOĞLU, S.; ULUSOY, E.; BALTAC, C.; CANDAN, F.. Biological activities and chemical composition of three honeys of different types from Anatolia. Food Chemistry, v.100, p.526-534, 2007. DOI: http://doi.org/10.1016/j.foodchem.2005.10.010

LACERDA, J. J. DE J.; SANTOS, J. S.; SANTOS, S. A.;
RODRIGUES, G. B.; SANTOS, M. L. P.. Influência das características físico-químicas e composição elementar nas cores de méis produzidos por Apis mellifera no sudoeste da Bahia utilizando análise multivariada. Química Nova, São

Paulo, v.33, p.1022-1026, 2010. DOI:

http://doi.org/10.1590/S0100-40422010000500003

LANARA. Laboratório Nacional de Referência Animal. Métodos analíticos oficiais para controle de produtos de origem animal e seus ingredientes. II - Métodos físicos e químicos. Mel. Ministério da Agricultura. Brasília: v. 2, p. 115,1981

LONGO, L.. Caracterização da apicultura na Baixada Cuiabana no Pantanal matogrossense. Dissertação (Mestrado em Ciências Ambientais) - Universidade do Estado de Mato Grosso, Cáceres, 2013.

MATO GROSSO (Estado); Secretaria de Estado de Planejamento e Coordenação Gera, SEPLAN: Cuiabá, 2013.

MEDA, A.; LAMIEN, C. E.; ROMITO, M.; MILLOGO, J.; NACOULMA, O. G.. Determination of the total phenolic, flavonoid and proline contents in Burkina Fasan honey, as well as their radical scavenging activity. Food Chemistry, v.91, p.571-577, 2005. DOI: http://doi.org/10.1016/j.foodchem.2004.10.006

MERCÊS, M. D.; PERALTA, E. D.; UETANABARO, A. P. T.; LUCCHESE, A. M.. Atividade antimicrobiana de méis de cinco espécies de abelhas brasileiras sem ferrão. Ciência Rural, Santa Maria, v.43, n.4, p.672-675, 2013

MESQUITA, A. M. R. C.; LEAL LIMA, N.; MOREIRA LIMA, A. A.. Avaliação da susceptibilidade e resistência antimicrobiana de cepas de Shigella spp. isoladas de pacientes com diarréia nosocomial. Revista de Ciências Médicas e Biológicas, Salvador, v.8, n.3, p.292-300, 2009.

MIGUEL, M. G.; FALEIRO, L.; ANTUNES, M. D.; AAZZA, S.; DUARTE, J.; SILVÉRIO, A. R.. Antimicrobial, antiviral and antioxidant activities of "água-mel" 'from Portugal. Food and Chemical Toxicology, v.56, p.136-144, 2013. DOI: http://doi.org/10.1016/j.fct.2013.02.007

MOLAN, P.. Not all honeys are the same for wound healing. European Tissue Repair Society, v.9, p.5-6, 2002.

NCCLS. National Committee for Clinical Laboratory Standards. Performance Standards for Antimicrobial Disk Susceptibility Tests, v. 27, Wayne: Pennsylvania, 2003.

OSTROSKY, E. A.; MIZUMOTO, M. K.; LIMA, M. E. L.; KANEKO, T. M.; NISHIKAWA, S. O.; FREITAS, B. R.. Métodos para avaliação da atividade antimicrobiana e determinação da concentração mínima inibitória (CMI) de plantas medicinais. Brazilian Journal of Pharmacognosy, v.18, p.301-307, 2008. ISSN 0102-695X

PAULINO, R. S.; MARCUCCI, M. C.. Análises físico químicas de méis do Ceará. Revista de Pesquisa e Inovação Farmacêutica, v.1, n.1, p.63-78, 2009.

PONTARA, L. P. M.; CLEMENTE, E.; OLIVEIRA, D. M.; KWIATKOWSKI, A.; ROSA, C. I. L. F.; SAIA, V. E..

Physicochemical and microbiological characterization of cassava flower honey samples produced by africanized 
honeybees. Ciência e Tecnologia de Alimentos, Campinas, v.32, n.3, p.547-552, 2012

RIZELIO, V. M.. Caracterização química do mel catarinense: composição, atividade antioxidante e o uso da eletroforese capilar como alternativa na avaliação da qualidade. Dissertação (Mestrado em Ciência dos Alimentos) Universidade Federal de Santa Catarina, Florianópolis, 2011.

SANDE, S. O.; CREWE, R. M.; RAINA, S. K.; NICOLSON, S. W.; GORDON, I.. Proximity to a forest leads to higher honey yield: another reason to conserve. Biological Conservation, v.142, p.2703-2709, 2009. DOI:

http://doi.org/10.1016/j.biocon.2009.06.023

SANT'ANA, L.; SOUSA, J.; SALGUEIRO, F.; AFFONSO, M. C.; CASTRO, R.. Characterization of Monofloral Honeys with multivariate analysis of their chemical profile and antioxidant activity. Journal of Food Science, v.71, p.C135C140, 2012. DOI: http://doi.org/10.1111/j.17503841.2011.02490.x

SANTOS, D. C.; OLIVEIRA, E. N. A.; MARTINS, J. N.; ALBUQUERQUE, E. M. B.. Qualidade fisico-química e microbiológica do mel de Apis mellifera comercializado na cidade de Russas, CE. Tecnologia e Ciência Agropecuária, João Pessoa, v.5, p.41-45, 2010.

SCALABRIN, R.; BUSS, G. D.; IAMAGUCHI, K. C. S.; CARDOSO, C. L.; GARCIA, L. B.. Isolamento de Streptococcus pyogenes em indivíduos com faringoamigdalite e teste de susceptibilidade a antimicrobianos. Revista Brasileira de Otorrinolaringologia, v.69, n.6, p.814-8, 2003.

SHERLOCK, O.; DOLAN, A.; ATHMAN, R.; POWER, A.; GETHIN. G.; COWMAN, S.; HUMPHREYS, H.. Comparison of the antimicrobial activity of Ulmo honey from Chile and Manuka honey against methicillin-resistant Staphylococcus aureus, Eshcerichia coli and Pseudomonas aeruginosa. BMC Complementary and Alternative Medicine, v.10, n.47, p.15, 2010. DOI: http://doi.org/10.1186/1472-6882-10-47

SILICI, S.; SAGDIC, O.; EKICI, L.. Total phenolic content, antiradical, antioxidant and antimicrobial activities of Rhododendron honeys. Food Chemistry, v.121, p.238-243, 2010. DOI: http://doi.org/10.1016/i.foodchem.2009.11.078

SINGLETON, V. L.; ROSSI, J. A. JR.. Colorimetry of total phenolics with phosphomolybdic-phosphotungstic acid reagents. American Journal of Enology and Viticulture, v.16, p.144-158, 1985.

TESSMANN, C.; ZOCCHE, F.; LIMA, A. S.; BASSANI, M.; LOPES, G. V.; PADILHA DA SILVA, W.. Ocorrência e perfil de sensibilidade a antibióticos de Salmonella spp. isolada em cortes de carne suína comercializados em feiras-livres de Pelotas (RS). Boletim do Centro de Pesquisa de Processamento de Alimentos, v.26, n.2, p.307-313, 2008. DOI: http://doi.org/10.5380/cep.v26i2.13294

VILHENA, F.; ALMEIDA-MURADIAN, L. B.. Análises físicoquímicas de méis de São Paulo. Mensagem Doce, v.53, p.1719, 1999

VOIDAROU, C.; ALEXOPOULOS, A.; PLESSAS, S.; KARAPANOU, A.; MANTZOURANI, I.; STAVROPOULOU, E.; FOTOU, K.; TZORA, A.; SKOUFOS, I.; BEZIRTZOGLOU, E.. Antibacterial activity of different honeys against pathogenic bactéria. Anaerobe, v.17, p.375-379, 2011. DOI: http://doi.org/10.1016/j.anaerobe.2011.03.012

VORWOHL, G.. Die Beziehung zwischen der elektrischen Leitfähigkeit der Honige und ihrer trachmässiger Herkunft. Ann. de Abeille, v.7, n.4, p.301-309, 1964.

YAO, L.; DATTA, N.; TOMÁS-BARBERÁN, F. A.; FERRERES, F.; MARTOS, I.; SINGANUSONG, R.. Flavonoids, phenolic acids and abscisic acid in Australian and New Zealand Leptospermum honeys. Food Chemistry, v.81, p.159-168, 2003. DOI: http://doi.org/10.1016/S0308-8146(02)00388-6

ZANATTA, G. F.; KANASHIRO, A. M. I.; CASTRO, A. G. M.; CARDOSO, A. L. S. P.; TESSARI, E. N. C.; PULICI, S. C. P.. Suscetibilidade de amostras de Escherichia coli de origem aviária a antimicrobianos. Arquivos do Instituto Biológico, v.71, n.3, p.283-286, 2004.

A CBPC - Companhia Brasileira de Produção Científica (CNPJ: 11.221.422/0001-03) detém os direitos materiais desta publicação. Os direitos referem-se à publicação do trabalho em qualquer parte do mundo, incluindo os direitos às renovações, expansões e disseminações da contribuição, bem como outros direitos subsidiários. Todos os trabalhos publicados eletronicamente poderão posteriormente ser publicados em coletâneas impressas sob coordenação da Sustenere Publishing, da Companhia Brasileira de Produção Científica e seus parceiros autorizados. Os (as) autores (as) preservam os direitos autorais, mas não têm permissão para a publicação da contribuição em outro meio, impresso ou digital, em português ou em tradução. 